\title{
The effect of saxitoxin and non-saxitoxin extracts of Cylindrospermopsis raciborskii (Cyanobacteria) on cyanobacteria and green microalgae
}

\author{
Maria do Carmo Bittencourt-Oliveira • Mathias Ahii Chia • \\ Danilo Camargo-Santos • Carlos T. S. Dias
}

Received: 21 October 2014 / Revised and accepted: 19 January 2015 / Published online: 3 February 2015

(C) Springer Science+Business Media Dordrecht 2015

\begin{abstract}
The effect of saxitoxins (STX) on phytoplankton species is poorly understood. To date, no correlation between STX concentrations and phytoplankton physiology has been reported. We investigated the effect of STX (STX+, 0.5$10 \mu \mathrm{g} \mathrm{L}^{-1}$ total STX) and non-STX (STX-, 0.5-10 $\mu \mathrm{g} \mathrm{L}^{-1}$ total STX biomass equivalent) extracts of Cylindrospermopsis raciborskii on Microcystis wesenbergii BCCUSP11, Microcystis aeruginosa BCCUSP232 (microcystin producing), Scenedesmus acuminatus UFSCar036, and Monoraphidium convolutum CMEA/UFF0201 under controlled laboratory conditions. Both STX+ and STX- extracts inhibited the cell density and specific growth rate of $M$. wesenbergii, M. aeruginosa, and S. acuminatus. However, the effect of STX+ extract on the phytoplankton strains was significantly higher than that of STX- extract. M. convolutum, on the other hand, was tolerant as both STX+ and STXextracts did not significantly reduce its cell density and specific growth rate $\left(\right.$ day $\left.^{-1}\right)$. The exposure of $M$. aeruginosa to STX+ and STX- resulted in higher total (intracellular and extracellular) microcystin concentration than the control. STX concentrations had a significant negative correlation with cell density and growth response of the phytoplankton strains
\end{abstract}

M. Bittencourt-Oliveira $(\bowtie) \cdot$ M. A. Chia $\cdot$ D. Camargo-Santos Department of Biological Sciences, Luiz de Queiroz College of Agriculture, University of São Paulo, Piracicaba, SP 13418-900, Brazil

e-mail: mbitt@usp.br

D. Camargo-Santos

Institute of Biological Sciences, São Paulo State University, Rio Claro, SP 13506-900, Brazil

C. T. S. Dias

Department of Exact Sciences, Luiz de Queiroz College of Agriculture, University of São Paulo, Piracicaba, SP 13418-900, Brazil investigated in this study. Conclusions can be made that although both STX+ and STX- extracts of C. raciborskii inhibited the growth of some phytoplankton species, the STX+ extracts were more toxic.

Keywords Growth inhibition · Cyanotoxins ·

Phytoplankton · dc-Saxitoxin · Neo-saxitoxin · Microcystins

\section{Introduction}

The potential of cyanobacteria to produce toxins makes their excessive proliferation a serious environmental problem (Chia et al. 2009a, b). Among the toxins produced by cyanobacteria, saxitoxins (STX) are alkaloids associated with paralytic shellfish poisoning (PSP) in freshwater ecosystems (Al-Tebrineh et al. 2010). The toxins affect cellular homeostasis by acting on sodium channels in both prokaryotes and eukaryotes (Neilan et al. 2013). STX are of high ecotoxicological risk due to the toxicity they induce in fish, mussels, copepods, mammals, and birds (Landsberg 2002). A number of cyanobacteria such as Aphanizomenon flos-aquae, Cylindrospermopsis raciborskii, Lyngbya spp., and Anabaena spp. synthesize STX in freshwater ecosystems. However, the production of this group of toxins tends to be strain specific (Molica et al. 2002; Bernard et al. 2003; Wiegand and Pflugmacher 2005; Al-Tebrineh et al. 2010). The discovery that $C$. raciborskii produces STX and cylindrospermopsin has made it an important cyanobacterium to be monitored in aquatic ecosystems. This is due to the increased frequency of its occurrence, scientific interest, improved water quality monitoring, availability of suitable habitat, and in some cases, its invasion of new habitats (Figueredo et al. 2007; Kling 2009; Sukenik et al. 2012). The cosmopolitan and increasing distribution of $C$. raciborskii is easily traced to its ecophysiological adaptation and tolerance to changing physicochemical 
conditions in water bodies (Carneiro et al. 2013). The strains isolated from South America have been implicated for only STX production (Lagos et al. 1999; Molica et al. 2002; Costa et al. 2013; Hoff-Risseti et al. 2013).

Although a number of studies have shown that STXproducing cyanobacteria and dinoflagellates exhibit allelopathic effects on phytoplankton species, no direct correlation with STX has been reported (Tillmann and John 2002; Fistarol et al. 2004; Tillmann et al. 2008; Hattenrath-Lehmann and Gobler 2011). To the best of our knowledge, only one study using Chlamydomonas reinhardtii as a model organism showed that the microalga suffered oxidative stress after exposure to STX (Melegari et al. 2012). Therefore, generalizations cannot be made for microalgal response to STX based on the findings with $C$. reinhardtii alone (Perreault et al. 2011; Melegari et al. 2012). Ecotoxicological investigations that employ microalgae are of great significance because they can demonstrate the toxicity of bioactive compounds on different levels of the food chain. Studies of the effect of STX are important because microalgae possess characteristics such as voltage-dependent ion channels, photosynthetic ability, cellular metabolism, and structural specializations that are different from those found in animals (Wheeler and Brownlee 2008; Taylor 2009). This implies that STX interaction with algal cells may be very different from that with animal cells (Taylor 2009; Melegari et al. 2012).

To date, the ecological role of cyanotoxins remains generally unknown; however, according to one of the hypotheses, they may be associated with phytoplankton competition (BarYosef et al. 2010; Rzymski et al. 2014). Microcystins (MC) are among the most studied cyanotoxins, and their production has been established to be geared toward giving the producer(s) a competitive advantage over neighboring species (Bittencourt-Oliveira et al. 2015). Furthermore, as a defense against predation, cyanobacteria (e.g., Microcystis aeruginosa) upregulate the synthesis of MC and other bioactive secondary metabolites (Pineda-Mendoza et al. 2014). However, a number of studies exclude this hypothesis due to lack of correlation between the production of $\mathrm{MC}$ and the rate of predation (Van Gremberghe et al. 2009; Wilken et al. 2010). The production of MC has also been shown to be regulated by physicochemical factors as well as the presence of chemical exudates from toxigenic and nontoxigenic algae (Downing et al. 2005; Deblois and Juneau 2010). Hence, we hypothesize that when threatened by the presence of cyanotoxins like STX, cyanobacteria can respond by upregulating $\mathrm{MC}$ synthesis as a defense mechanism.

Successional studies show that the occurrence of Cylindrospermopsis blooms is usually accompanied by the presence of chlorophytes of the genera Monoraphidium and Scenedesmus (Bouvy et al. 1999, 2006; Kokociński et al. 2010). Furthermore, there is evidence of the alternation between the dominance of green microalgae and cyanobacteria in different aquatic ecosystems (Zalocar de Domitrovic et al. 2007; Chia et al. 2012). However, the chemical interactions involved in this successional process are still not comprehensively understood. Previous studies have shown that some green algae are tolerant to MC (Bártová et al. 2011; Campos et al. 2013; Bittencourt-Oliveira et al. 2015), while not much is known about how STX affect green microalgae.

The objective of this study was to determine the effect of STX and non-STX extracts of C. raciborskii on the growth of green microalgae (Scenedesmus acuminatus and Monoraphidium convolutum) and cyanobacteria (Microcystis wesenbergii and M. aeruginosa). Furthermore, total (intracellular and extracellular) MC production by $M$. aeruginosa after exposure to STX and non-STX extracts of $C$. raciborskii was investigated. The results of the present study demonstrate for the first time the effect of STX on different phytoplankton species.

\section{Materials and methods}

The phytoplankton strains used in this study were Microcystis wesenbergii BCCUSP11 and Microcystis aeruginosa BCCUSP232 obtained from the Brazilian Cyanobacteria Collection of University of São Paulo (BCCUSP), Scenedesmus acuminatus UFSCar036 from the Microalgal Collection of Federal University of São Carlos (UFSCar), and Monoraphidium convolutum CMEA/UFF0201 from the Elizabeth Aidar Collection of Microalgae (CMEA/UFF). The M. aeruginosa BCCUSP232 strain is a MC-producing strain (BittencourtOliveira 2003), while $M$. wesenbergii BCCUSP11 is a non-MCproducing strain (Bittencourt-Oliveira et al. 2011). All strains were maintained in ASM-1 liquid medium (Guillard 1973) at pH 7.4 using climatic chambers with controlled light intensity $(40 \mu \mathrm{mol}$ photons $\mathrm{m}^{-2} \mathrm{~s}^{-1}$, measured with a LI-COR model LI-250 photometer equipped with an underwater spherical sensor), photoperiod (14:10 h, light/dark), and temperature $\left(24 \pm 1^{\circ} \mathrm{C}\right)$.

Preparation and quantification of cyanobacterial extracts

The STX and non-STX extract sources were $C$. raciborskii ITEPA1 and C. raciborskii ITEP31, respectively. Both C. raciborskii strains were obtained from the Cyanobacterial Collection of the Technological Institute of Pernambuco (ITEP), Brazil. The biomass required for extract preparation was obtained by culturing approximately $20 \mathrm{~L}$ of each C. raciborskii strain under the controlled conditions stated above. At exponential growth phase, the cultures were centrifuged at $9500 \mathrm{rcf}$ for $15 \mathrm{~min}$ at $20^{\circ} \mathrm{C}$, and the resulting pellet was lyophilized and stored at $-80^{\circ} \mathrm{C}$ until needed.

Total STX concentration in the STX+ crude extract was determined following the procedures outlined in Oshima (1995). Briefly, the lyophilized material was extracted in 
$0.05 \mathrm{~N}$ acetic acid. The extract was analyzed using highperformance liquid chromatography (HPLC) equipped with an online postcolumn fluorescence derivatization system (Shimadzu, Japan). The different STX variants were identified and quantified by comparison with the retention time and the areas of standard peaks. The standards ( $\geq 98 \%$ purity) were purchased from the National Research Council, CanadaCertified Reference Materials Program. The HPLC analysis results showed that dc-saxitoxin $\left(0.41 \mu \mathrm{g} \mathrm{mg}^{-1}, 62.58 \%\right)$, neo-saxitoxin $\left(0.21 \mathrm{\mu g} \mathrm{mg}^{-1}, 32.50 \%\right)$, and saxitoxin $\left(0.03 \mu \mathrm{g} \mathrm{mg}^{-1}, 4.90 \%\right)$ made up the total STX produced by C. raciborskii ITEPA1 (STX+).

Preparation and addition of aqueous crude extract to the cultures

Crude aqueous extracts were prepared from $76 \mathrm{mg}$ of lyophilized biomass. The biomass was resuspended in $8 \mathrm{~mL}$ autoclaved deionized water and ultrasonicated at $15 \mathrm{~W}$ and $22.5 \mathrm{kHz}$ for $5 \mathrm{~min}$ (Microson Ultrasonic Cell Disruptor, USA), to obtain an initial concentrated total STX solution. Subsequently, this initial concentrated total STX solution was serially diluted to arrive at the desired final exposure concentrations of $0.5,1.0,5.0$, and $10.0 \mu \mathrm{g} \mathrm{L}^{-1}$ total STX, which corresponded to $0.75,1.5,7.5$, and $15 \mathrm{mg} \mathrm{L}^{-1}$ C. raciborskii wet weight, respectively. For the non-STX (STX-) treatments, the lyophilized biomass was extracted following the same procedures as the STX+-containing biomass, and the extracts were added to the cultures at equivalent biomass of the STX+ extracts.

\section{Experimental design}

The cyanobacteria and green algae were exposed separately to STX+ and STX- extracts for 10 days. The extracts were added to the cultures on day 4 of the experiment. The cultures were maintained in climatic chambers set to luminous intensity of $40 \mu \mathrm{mol}$ photons $\mathrm{m}^{-2} \mathrm{~s}^{-1}$, photoperiod 14:10 h (light/ dark), and temperature $24 \pm 1{ }^{\circ} \mathrm{C}$. For each experiment, $1000 \mathrm{~mL}$ Erlenmeyer flasks containing $600 \mathrm{~mL}$ of ASM-1 culture medium were used. All experiments were carried out in triplicates. The initial cell density for all experimental treatments was $1.0 \times 10^{5}$ cells $\mathrm{mL}^{-1}$.

Determination of cell density and specific growth rates

Aliquots $(2 \mathrm{~mL})$ were taken every 2 days throughout the experiment and preserved in $10 \%$ Lugol's solution for microscopic analysis. Estimation of cell density was done microscopically using a Fuchs-Rosenthal counting chamber according to Guillard (1973). In order to obtain reliable results, a minimum of 400 cells were counted to maintain the error within $\pm 10 \%$ (Lund et al. 1958).
Specific growth rate $\left(\right.$ day $\left.^{-1}\right)$ was calculated according to the equation:

$\mu=\operatorname{Ln}\left(N_{t} / N_{0}\right) / t$

where $\mu$ is the growth rate, $N_{t}$ is the cell number at time $t$, and $N_{0}$ is the cell number at time zero (right after the inoculation).

Cyanotoxin analyses during culture experiments

Immediately after the addition of the STX+ extract to the cultures, $1 \mathrm{~mL}$ aliquots were taken to confirm the concentrations of neo-STX and STX added. In addition, at the end of the experiment, $1 \mathrm{~mL}$ aliquots were collected to obtain final neoSTX and STX concentrations. For MC quantification, $1 \mathrm{~mL}$ aliquots were taken on days 4 and 14 of the experiment to determine the effect of the different STX+ and STX- treatments on total (intracellular and extracellular) MC production by $M$. aeruginosa BCCUSP232. All samples for cyanotoxin analyses were stored at $-80^{\circ} \mathrm{C}$. Just before analyses, the samples were thawed and ultrasonicated for $3 \mathrm{~min}(15 \mathrm{~W}$ and $22.5 \mathrm{kHz}$ ) in an ice bath to lyse the cells.

The determination of neo-STX, STX, and total MC concentrations was carried out using Beacon ELISA plate kits (Beacon Analytical Systems, USA) specific to each cyanotoxin. All analyses were done following the manufacturer's instructions. The analyses were performed in triplicate and the results were expressed in $\mu \mathrm{g} \mathrm{L}^{-1}$. STX analyses revealed that neo-STX had the highest degradation $(>90 \%)$ at the end of the experiment, while that of STX was lower than $50 \%$ of the initial concentrations in most cases (Table 1).

\section{Statistical analyses}

Biomass production and specific growth rate data were first subjected to normality and homoscedasticity tests. Repeatedmeasures ANOVA and Tukey's tests were carried out to determine significant differences between cell densities and specific growth rates under the different treatment conditions. A correlation-based principal components analysis was used to determine possible relationships between the treatments and the response variables. All analyses were done at $5 \%$ significance level.

\section{Results}

The exposure of $M$. aeruginos $a$ and $M$. wesenbergii to STX+ extracts resulted in a significant decrease in the cell density of both strains. The STX- extracts caused a slight reduction in the cell density of both cyanobacterial strains (Fig. 1a-d). Among the green microalgae, only $S$. acuminatus was significantly affected by both STX + and STX- crude 
Table 1 Changes in total saxitoxins and saxitoxin variant concentrations in the beginning and at the end of the experiments with selected cyanobacterial and green microalgal strains. Decay (\%) of initial concentration of neo-STX and STX

\begin{tabular}{|c|c|c|c|c|c|c|c|}
\hline \multirow[t]{2}{*}{ Target strain } & \multirow[t]{2}{*}{ Total STX concentration } & \multicolumn{2}{|c|}{ Initial concentrations } & \multicolumn{2}{|c|}{ Final concentrations } & \multicolumn{2}{|l|}{ Decay (\%) } \\
\hline & & Neo-STX & STX & Neo-STX & STX & Neo-STX & STX \\
\hline \multirow[t]{4}{*}{ M. wesenbergii BCCUSP11 } & 0.5 & $0.694 \pm 0.140$ & $0.185 \pm 0.002$ & $0.133 \pm 0.030$ & $0.136 \pm 0.001$ & $81 \%$ & $26 \%$ \\
\hline & 1.0 & $1.269 \pm 0.069$ & $0.716 \pm 0.040$ & $0.094 \pm 0.011$ & $0.293 \pm 0.021$ & $93 \%$ & $59 \%$ \\
\hline & 5.0 & $3.192 \pm 0.164$ & $1.093 \pm 0.062$ & $0.113 \pm 0.011$ & $0.503 \pm 0.059$ & $96 \%$ & $53 \%$ \\
\hline & 10.0 & $3.900 \pm 0.383$ & $1.886 \pm 0.177$ & $0.289 \pm 0.024$ & $1.067 \pm 0.069$ & $93 \%$ & $43 \%$ \\
\hline \multirow[t]{4}{*}{ M. aeruginosa BCCUSP232 } & 0.5 & $0.609 \pm 0.140$ & $0.173 \pm 0.010$ & $0.132 \pm 0.009$ & $0.070 \pm 0.005$ & $78 \%$ & $59 \%$ \\
\hline & 1.0 & $0.580 \pm 0.045$ & $0.338 \pm 0.005$ & $0.176 \pm 0.047$ & $0.206 \pm 0.015$ & $70 \%$ & $39 \%$ \\
\hline & 5.0 & $1.426 \pm 0.316$ & $0.956 \pm 0.047$ & $0.358 \pm 0.026$ & $0.855 \pm 0.064$ & $75 \%$ & $10 \%$ \\
\hline & 10.0 & $4.811 \pm 0.482$ & $1.950 \pm 0.115$ & $0.217 \pm 0.043$ & $1.280 \pm 0.071$ & $95 \%$ & $34 \%$ \\
\hline \multirow[t]{4}{*}{ S. acuminatus UFSCar036 } & 0.5 & $0.483 \pm 0.069$ & $0.153 \pm 0.016$ & $0.111 \pm 0.015$ & $0.149 \pm 0.010$ & $77 \%$ & $2 \%$ \\
\hline & 1.0 & $0.743 \pm 0.015$ & $0.507 \pm 0.016$ & $0.106 \pm 0.022$ & $0.267 \pm 0.007$ & $86 \%$ & $47 \%$ \\
\hline & 5.0 & $2.315 \pm 0.162$ & $1.126 \pm 0.106$ & $0.122 \pm 0.022$ & $0.710 \pm 0.075$ & $95 \%$ & $36 \%$ \\
\hline & 10.0 & $4.293 \pm 0.328$ & $1.740 \pm 0.082$ & $0.255 \pm 0.029$ & $1.073 \pm 0.013$ & $94 \%$ & $38 \%$ \\
\hline \multirow[t]{4}{*}{ M. convolutum $\mathrm{CMEA} / \mathrm{UFF} 0201$} & 0.5 & $0.406 \pm 0.057$ & $0.202 \pm 0.011$ & $0.178 \pm 0.015$ & $0.147 \pm 0.014$ & $56 \%$ & $27 \%$ \\
\hline & 1.0 & $0.652 \pm 0.008$ & $0.230 \pm 0.025$ & $0.311 \pm 0.012$ & $0.216 \pm 0.019$ & $52 \%$ & $6 \%$ \\
\hline & 5.0 & $1.693 \pm 0.331$ & $1.123 \pm 0.069$ & $0.053 \pm 0.007$ & $0.101 \pm 0.009$ & $97 \%$ & $90 \%$ \\
\hline & 10.0 & $3.329 \pm 0.416$ & $1.945 \pm 0.022$ & $0.095 \pm 0.011$ & $1.191 \pm 0.099$ & $97 \%$ & $38 \%$ \\
\hline
\end{tabular}

extracts, while M. convolutum showed no sensitivity to the extracts (Fig. 2a-d).

The exposure of the green microalgal and cyanobacterial strains to STX- and STX+ resulted in a significant reduction in their specific growth rates especially at the highest concentration $\left(10 \mu \mathrm{g} \mathrm{L}^{-1}\right)$ (Fig. 3). Among the four strains investigated, $S$. acuminatus and $M$. wesenbergii were the most sensitive to the STX+ and STX- extracts. However, the toxic effect of STX + on the investigated strains was higher than that of the STX- extract.

MC concentrations in M. aeruginosa BCCUSP232 cultures at the end of the experiment were significantly higher than those observed at the point of STX- and STX+ extract addition (Fig. 4). The higher the STX+ or STX- concentrations, the higher the $\mathrm{MC}$ content that was observed.

Principal components analysis (PCA) results of the STX+ and STX- experiments are given in Figs. 5 and 6, respectively. The PCA for STX+ treatments showed that the first two components accounted for over $90 \%$ of the total variation (Fig. 5). Cell density had a significant negative correlation with neo-STX and STX concentrations, while MC production by $M$. aeruginosa had a significant positive correlation with neo-STX and STX concentrations. On the second principal component, a negative relationship of total STX (treatments), neo-STX, and STX concentrations with specific growth rates of the two cyanobacterial and two green microalgal strains was obtained. For the STX- treatments (Fig. 6), MC production by $M$. aeruginosa was significantly positively correlated with the different STX- extract concentrations. Furthermore, the first two principal components accounted for over $98 \%$ of the total variations.

\section{Discussion}

During interspecific competition, the success of phytoplankton species is dependent on their physiological adaptation to changes in the environment or the production of bioactive substances to directly interfere with the growth of competing species (Dunker et al. 2013; Zhang et al. 2013). The effect of these compounds is contingent on their mode of action and the specific particularities of the species or strain under investigation (Perreault et al. 2011; Melegari et al. 2012). Our results indicated potential inhibitory effects of STX- and STX+ extracts on phytoplankton species, when the exposure concentrations were between $5 \mu \mathrm{g} \mathrm{L}^{-1}$ (or $16.7 \mathrm{nM}$ ) STX and above. In agreement with our findings, Fistarol et al. (2004) and Hattenrath-Lehmann and Gobler (2011) observed that filtrates of STX- and non-STX-producing strains of Alexandrium (dinoflagellate) inhibited the growth of competing species. Our results are slightly different because the STX-containing extracts were more toxic to three out of the four phytoplankton species investigated. Furthermore, Mello et al. (2012) showed that filtrates of STX-producing C. raciborskii not only inhibited growth but also retarded colony formation of M. aeruginosa, while Melegari et al. (2012) demonstrated that purified STX $(0.4-3.0 \mathrm{nM})$ induced oxidative stress in C. reinhardtii after $72 \mathrm{~h}$ incubation. Contrary to our findings, 

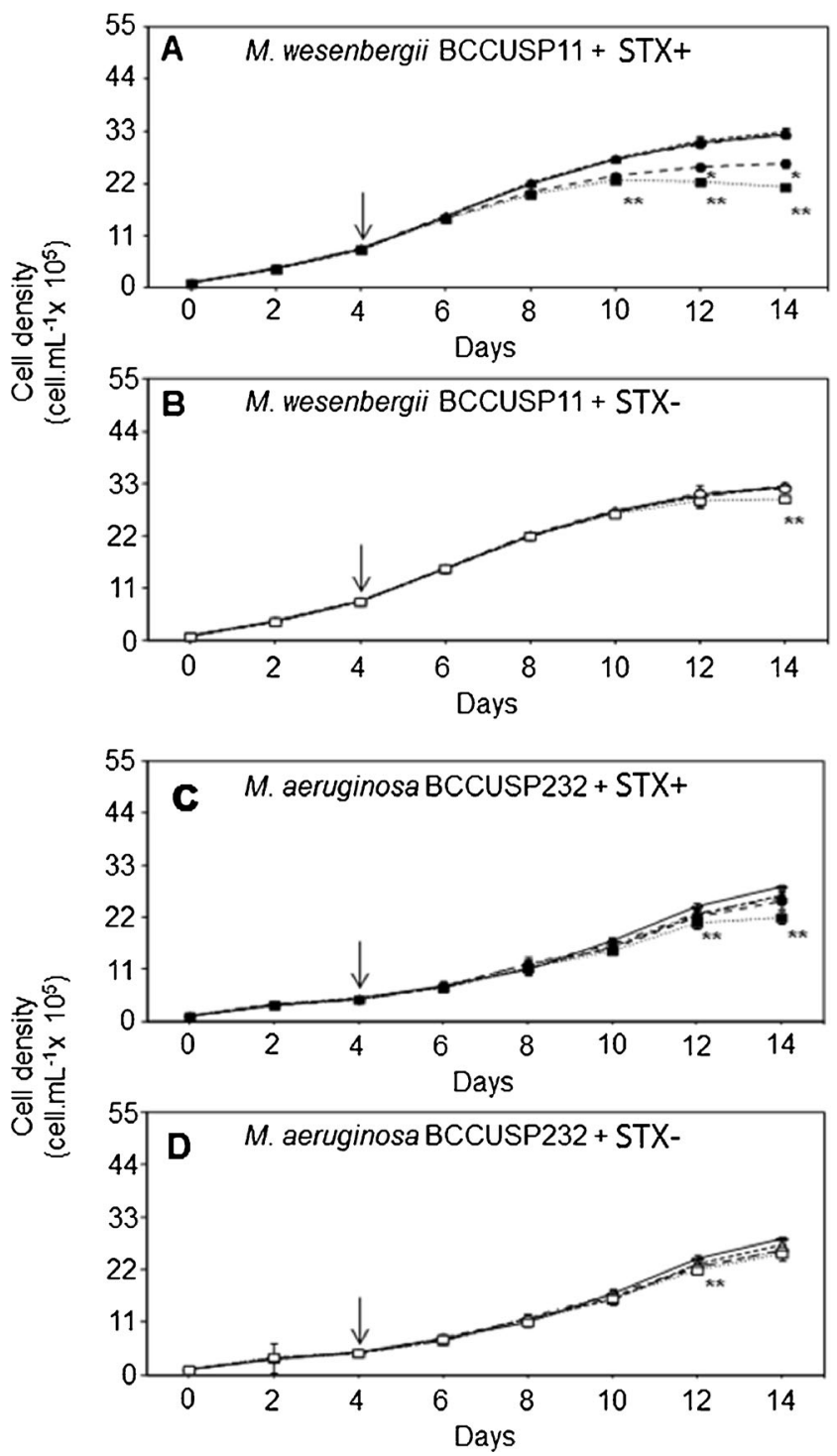

Fig. 1 Cell density of a M. wesenbergii BCCUSP11 exposed to C. raciborskii ITEPA1 STX+. b $M$. wesenbergii exposed to C. raciborskii ITEP31 STX-. c M. aeruginosa BCCUSP232 exposed to $C$. raciborskii ITEPA1 STX+. d $M$. aeruginosa BCCUSP232 exposed to $C$. raciborskii ITEP31 STX-. Control (solid line), 0.5 STX+ $\mu \mathrm{g} \mathrm{L}^{-1}$ (filled diamond and dashed line), 0.5 STX- $\mu \mathrm{g} \mathrm{L}^{-1}$ (empty diamond and dashed line), 1.0 STX $+\mu \mathrm{g} \mathrm{L}^{-1}$ (filled triangle and dashed line), 1.0 STX $-\mu \mathrm{g} \mathrm{L}^{-1}$ (empty triangle and dashed line), 5.0 STX $+\mu \mathrm{g}$ $\mathrm{L}^{-1}$ (filled circle and dashed line), 5.0 STX- $\mu \mathrm{g} \mathrm{L}^{-1}$ (empty circle and dashed line), 10.0 STX $+\mu \mathrm{g} \mathrm{L}^{-1}$ (filled square and dotted line), 10.0 STX $-\mu \mathrm{g} \mathrm{L}^{-1}$ (empty square and dotted line). Arrows represent addition of the extracts. Significant differences in cell density between treatments and control $5.0 \mu \mathrm{g} \mathrm{L}^{-1} \mathrm{STX}+\left(^{*}\right)$ and $10.0 \mu \mathrm{g} \mathrm{L}^{-1} \mathrm{STX}+(* *)$

Perreault et al. (2011) reported no inhibitory effect of purified STX $(2-128 \mathrm{nM})$ on $C$. reinhardtii after $96 \mathrm{~h}$ exposure. It is important to note that this difference may be because in addition to STX, there were other secondary metabolites present in the extracts used in our study, which probably interacted with STX to influence their effect on the phytoplankton species.
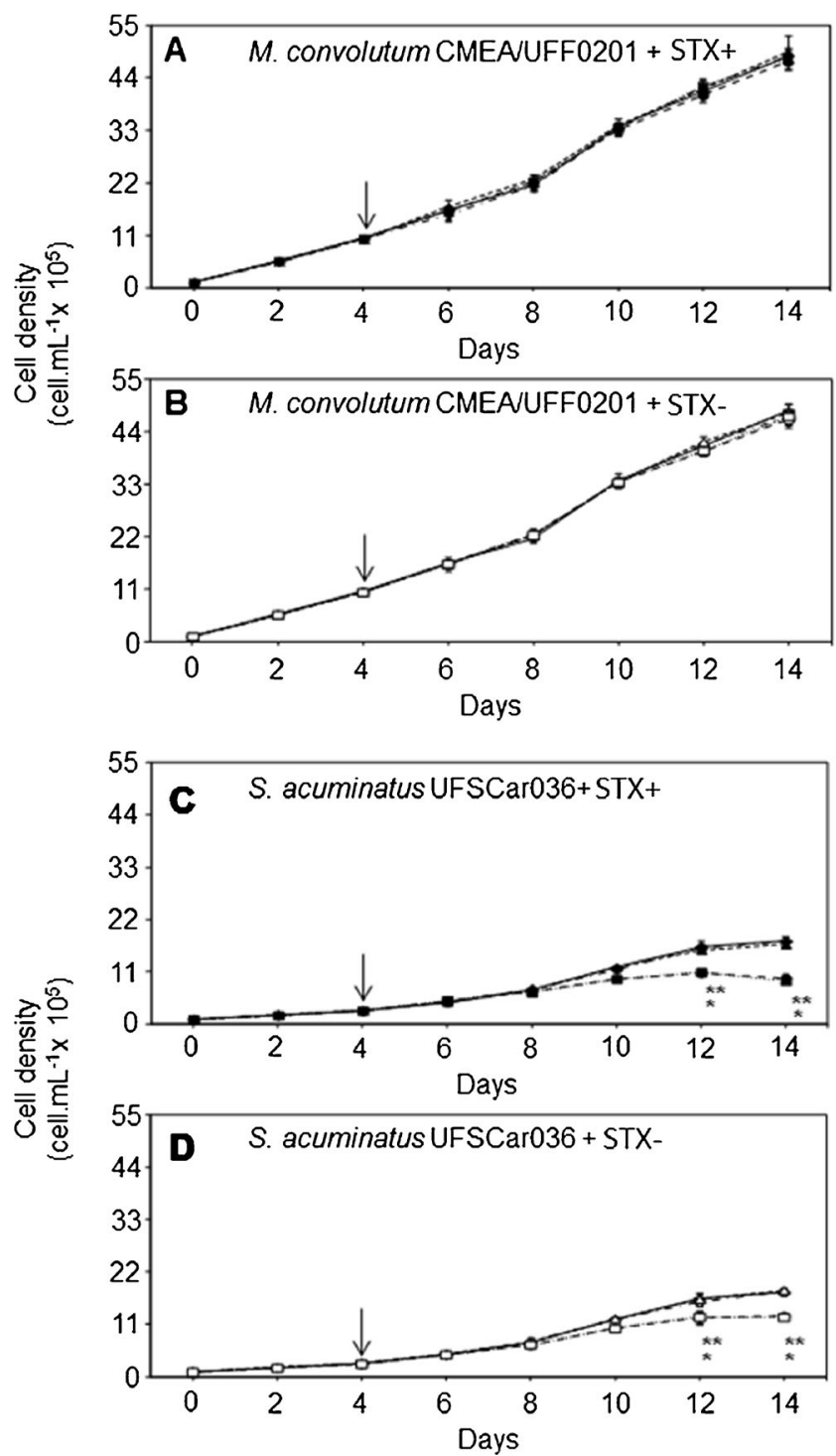

Fig. 2 Cell density of a M. convolutum CMEA/UFF0201 exposed to C. raciborskii ITEPA1 STX+. b $M$. convolutum CMEA/UFF0201 exposed to C. raciborskii ITEP31 STX-. c S. acuminatus UFSCar036 exposed to $C$. raciborskii ITEPA1 STX+. d S. acuminatus UFSCar036 exposed to $C$. raciborskii ITEP31 STX. Control (solid line), $0.5 \mathrm{STX}+\mu \mathrm{g}$ $\mathrm{L}^{-1}$ (filled diamond and dashed line), 0.5 STX $-\mu \mathrm{g} \mathrm{L}^{-1}$ (empty diamond and dashed line), 1.0 STX+ $\mu \mathrm{g} \mathrm{L}^{-1}$ (filled triangle and dashed line), 1.0 $\mathrm{STX}-\mu \mathrm{g} \mathrm{L}^{-1}$ (empty triangle and dashed line), 5.0 STX $+\mu \mathrm{g} \mathrm{L}^{-1}$ (filled circle and dashed line), 5.0 STX- $\mu \mathrm{g} \mathrm{L}^{-1}$ (empty circle and dashed line), $10.0 \mathrm{STX}+\mu \mathrm{g} \mathrm{L}^{-1}$ (filled square and dotted line), 10.0 STX- $\mathrm{S} \mathrm{L} \mathrm{L}^{-1}$ (empty square and dotted line). Arrows represent addition of the extracts. Significant differences in cell density between treatments and control $5.0 \mu \mathrm{g} \mathrm{L}^{-1} \mathrm{STX}+\left(^{*}\right)$ and $10.0 \mu \mathrm{g} \mathrm{L}^{-1} \mathrm{STX}+(* *)$

M. convolutum revealed some tolerance to both STX- and STX + extracts. Unlike the other phytoplankton species investigated, the cell density and specific growth rates of M. convolutum CMEA/UFF0201 were not significantly affected by STX+ and STX - extracts. Recent studies have demonstrated that green microalgae appear to be resistant to a number of cyanobacterial toxins at environmentally relevant 
Fig. 3 Specific growth of $S$. acuminatus, $M$. convolutum, M. wesenbergii, and M. aeruginosa exposed to extracts of $C$. raciborskii ITEPA1 STX+ and C. raciborskii ITEP31 STX-. Sac represents S. acuminatus; Mono, M. convolutum; M232, M. aeruginosa; $M 11$, M. wesenbergii. ${ }^{*} p<0.05$, means are significantly different from the control

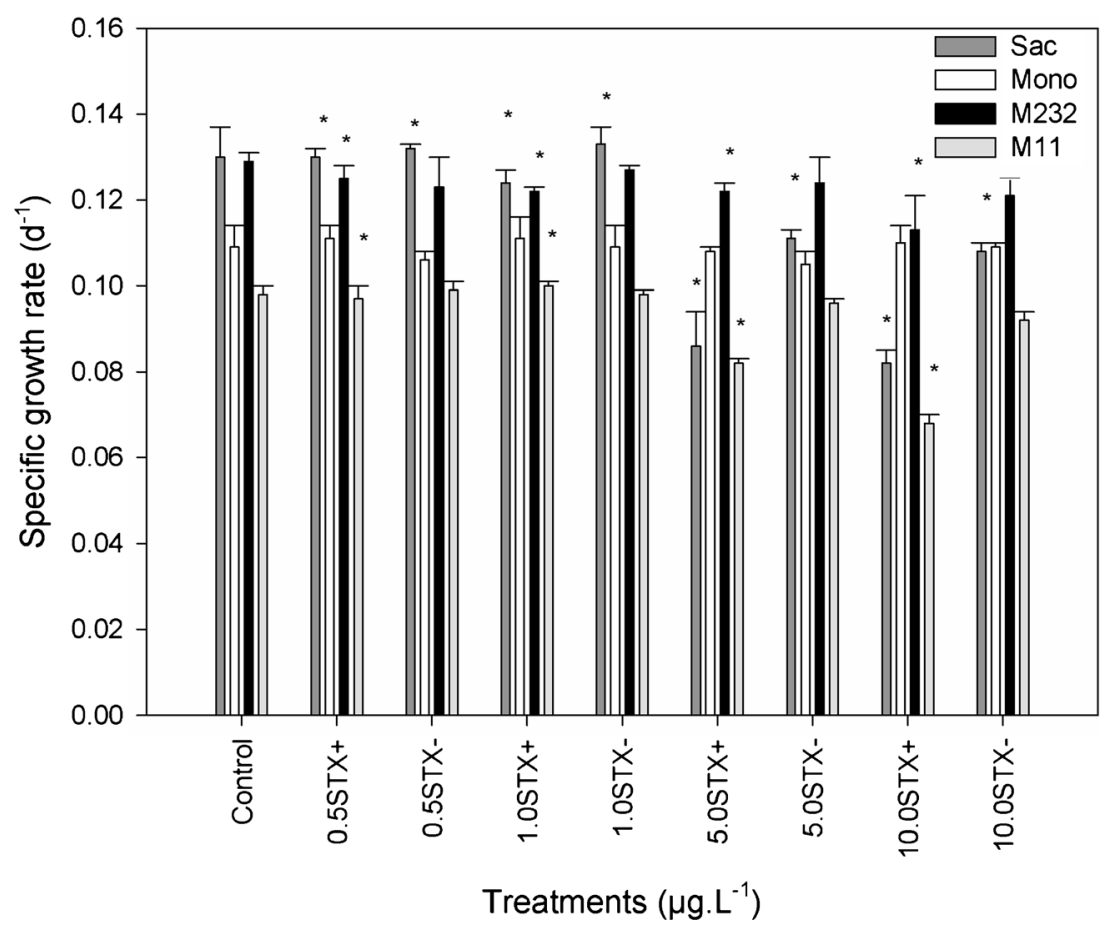

concentrations (Babica et al. 2007; Bártová et al. 2011; Campos et al. 2013; Bittencourt-Oliveira et al. 2015). In addition, Leão et al. (2009) reported that cell-free filtrates of "nontoxic" C. raciborskii had no significant effect on Ankistrodesmus falcatus and Chlorella vulgaris.

Non-STX-containing extracts of $C$. raciborskii also inhibited the growth of some of the investigated phytoplankton species.
Different "nontoxic" strains of this cyanobacterium have been reported to inhibit the growth of phytoplankton species (Suikkanen et al. 2004; Figueredo et al. 2007; Mello et al. 2012). However, there is growing evidence that the "nontoxic" strains of $C$. raciborskii may actually produce toxic (or bioactive) but unknown compounds with allelopathic potential (Acs et al. 2013; Rzymski and Poniedzialek 2014; Poniedzialek et al.
Fig. 4 Total microcystin production by Microcystis aeruginosa after exposure to saxitoxin $(\mathrm{STX}+)$ and non-saxitoxin (STX-) extracts of Cylindrospermopsis raciborskii. ${ }^{*} p<0.05$, means are significantly different from the control

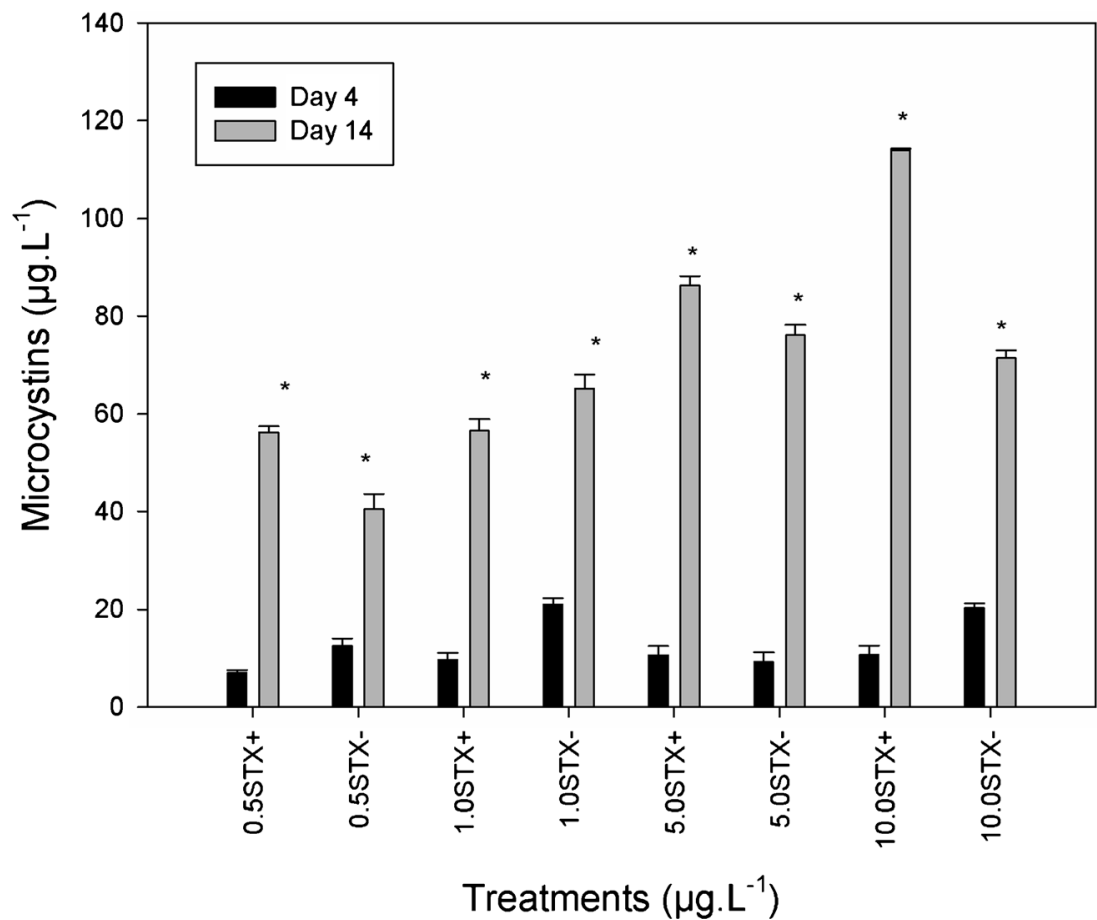


Fig. 5 PCA biplot showing the relationship of saxitoxin variants (neo-STX and STX) with cell density, microcystin production, and specific growth rates of the different phytoplankton species. MC232 represents microcystin S. acu, S. acuminatus cell density; Mono, M. convolutum cell density; M232, M. aeruginosa cell density; $M 11, M$. wesenbergii cell density. $S G R$ represents specific growth rates for $\mathrm{S}$. acu (S. acuminatus), Mono (M. convolutum), M232 (M. aeruginosa), and M11 (M. wesenbergii) production by $M$. aeruginosa;

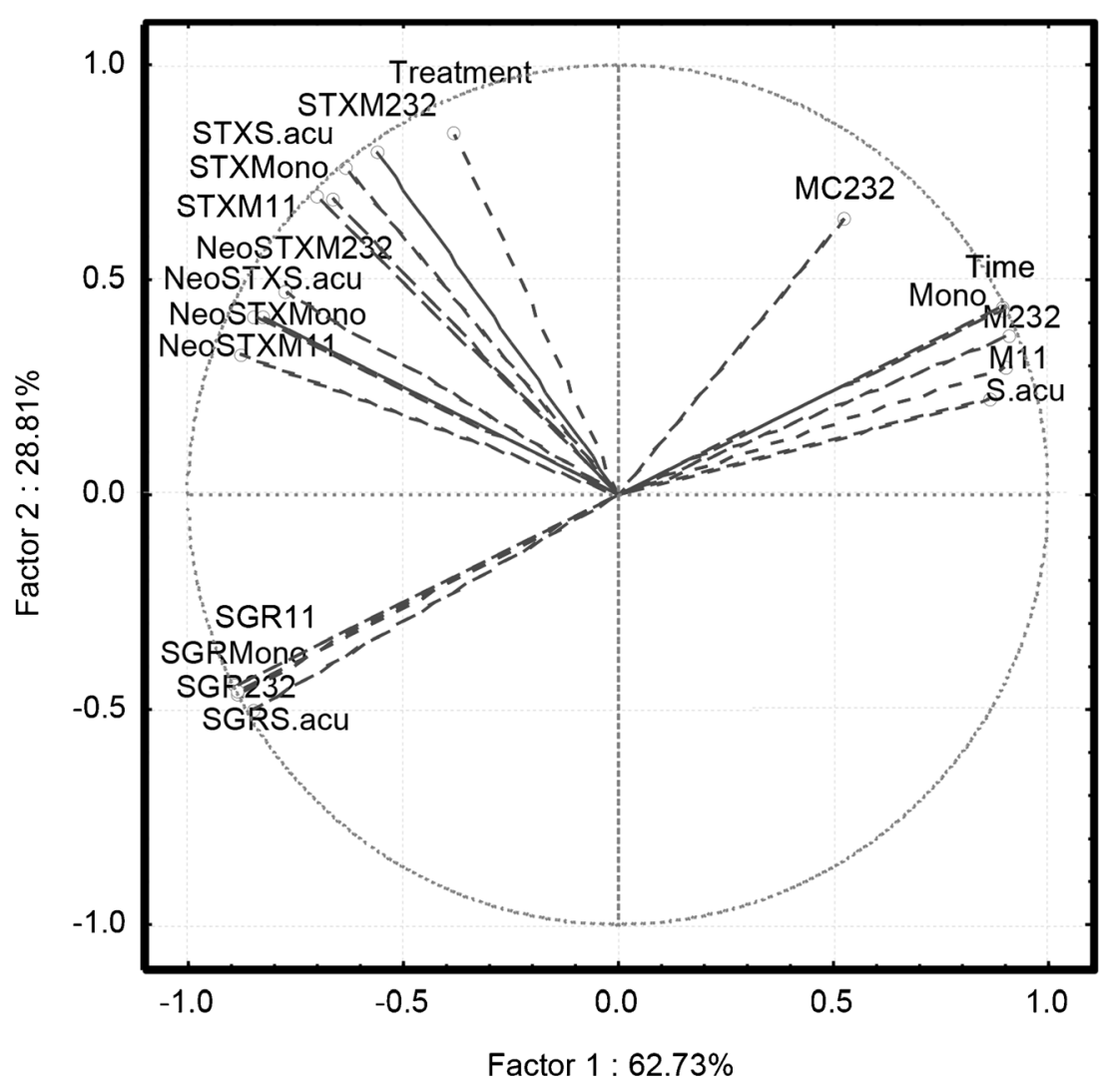

Fig. 6 PCA biplot showing the relationship of non-saxitoxin extracts $\left(\mathrm{STX}^{-}\right)$) with cell density, microcystin production, and specific growth rates of the different phytoplankton species. MC232 represents microcystin production by $M$. aeruginosa; S. acu, S. acuminatus cell density; Mono, M. convolutum cell density; M232, M. aeruginosa cell density; $M 11, M$. wesenbergii cell density. $S G R$ represents specific growth rates for $\mathrm{S}$. acu (S. acuminatus), Mono (M. convolutum), M232

(M. aeruginosa), and M11

(M. wesenbergii)

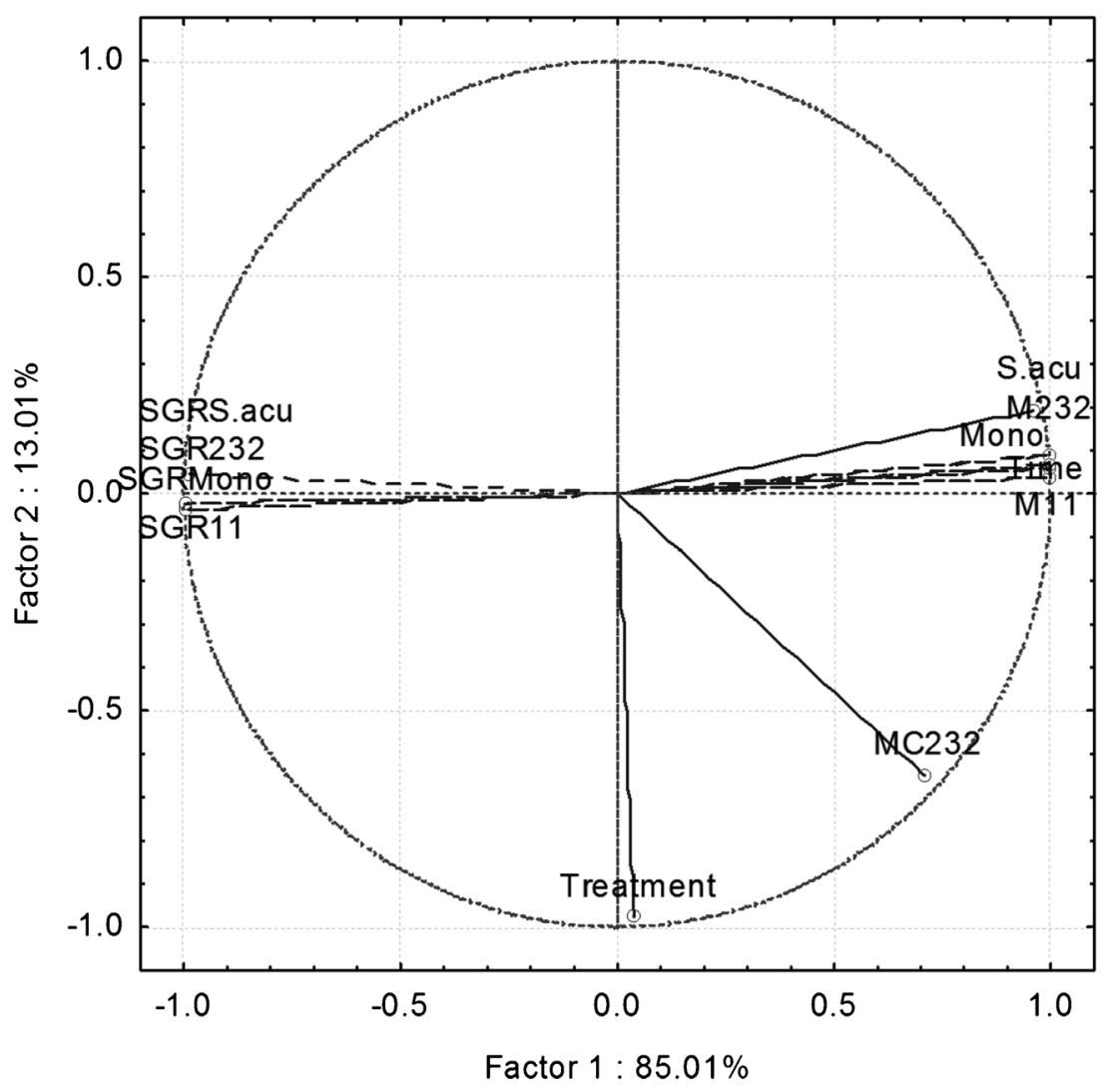


2015). This probably explains why the STX- strain was able to inhibit the growth of the phytoplankton species investigated in our study. However, the inhibition of phytoplankton growth by STX- extracts in our study was lower than that of the STX+ extracts. The greater inhibition by STX + suggests that there is a STX concentration-dependent toxicity with respect to cell density and specific growth rates. This supports the significant negative correlation found between the concentrations of the different STX variants (neo-STX and STX) with specific growth rate and cell densities of the sensitive phytoplankton strains. Thus, the effects of STX + extract on the phytoplankton species may be linked to a decrease in the number of cell divisions (HattenrathLehmann and Gobler 2011).

Recent studies have demonstrated that MC are responsible for the formation and maintenance of M. aeruginosa cell colonies (Schatz et al. 2007; Gan et al. 2012; Rzymski et al. 2014). Increased synthesis of MC has been reported to correlate with increased growth rate in $M$. aeruginosa, which promotes its competitiveness with other phytoplankton (Orr and Jones 1998; Kaplan et al. 2012) and defense against predation (Pineda-Mendoza et al. 2014). An inhibition of MC synthesis can lead to a decrease in the fitness of M. aeruginosa population. In this study, the exposure of $M$. aeruginosa BCCUSP232 to exogenous STX caused an increase in the production of MC. This explains the significant correlation observed between MC production by M. aeruginosa and the concentrations of the different STX variants observed in this study. The increased MC production observed in the present study may have been an adaptive strategy by the cyanobacterium to maintain and possibly increase its growth, under the influence of STX+ and STX- extracts. Another interesting phenomenon was observed with the STX- extracts, where the treatments only had a significant positive correlation with the production of MC by M. aeruginosa but not with its specific growth rates and cell density. Our previous study (Cordeiro-Araújo and Bittencourt-Oliveira 2013) showed that the active release of MC by M. aeruginosa BCCUSP232 was controlled by an endogenous rhythm, which explains the increased concentration of the toxin recorded at the end of the present investigation in all treatments and control. This means the active release of MC by M. aeruginosa was stimulated by the presence of bioactive substances produced by both strains of $C$. raciborskii.

It is important to note that in vitro studies cannot be directly extrapolated to field conditions. However, the STX concentrations used in the present study are comparable to those obtained under field conditions (Velzeboer et al. 2000). In addition, the effect of MC on STX-producing and non-STX-producing species remains unknown at the moment, which will form an important subject for future investigations. This is because C. raciborskii co-occurs or alternates with the studied green algae and cyanobacteria species in aquatic ecosystems (Moustaka-Gouni et al. 2007). Therefore, there may be several direct interference interactions taking place between these phytoplankton species that are not known at the moment.

In conclusion, our experiments showed that STX- and STX+ crude extracts of $C$. raciborskii were capable of inhibiting the growth of different phytoplankton species. This study provided for the first time a direct correlation of the presence and concentrations of STX variants with biomass production and specific growth rates of three out of the four phytoplankton species investigated. Furthermore, the STX+ extracts were more toxic to the phytoplankton species than the STX- extracts. In response to the presence of STX+ and STX- extracts, total (intracellular and extracellular) MC production by $M$. aeruginosa increased as a means maintaining its growth and probably combating the effects of $C$. raciborskii extracts.

Acknowledgments This research was supported by grants 2011/ 50840-0 and 2011/02957-5 from the São Paulo Research Foundation (FAPESP) and 301739/2011-0 from the National Council of Technological and Scientific Development $(\mathrm{CNPq})$ to M.C. Bittencourt-Oliveira. M.A. Chia acknowledges the postdoctoral fellowship (Grant No. 2013/11306-3) granted by the São Paulo Research Foundation (FAPESP).

\section{References}

Acs A, Kovács AW, Csepregi JZ, Toro N, Kiss G, Gyori J, Vehovszky A, Kovats N, Farkas A (2013) The ecotoxicological evaluation of Cylindrospermopsis raciborskii from Lake Balaton (Hungary) employing a battery of bioassays and chemical screening. Toxicon 70:98-106

Al-Tebrineh J, Mihali TK, Pomati F, Neilan BA (2010) Detection of saxitoxin-producing cyanobacteria and Anabaena circinalis in environmental water blooms by qualitative PCR. Appl Environ Microbiol 76:7836-7842

Babica P, Hilscherová K, Bártová K, Bláha L, Maršalék B (2007) Effects of dissolved microcystins on growth of planktonic photoautotrophs. Phycologia 46:137-142

Bártová K, Hilscherová K, Babica P, Maršálek B, Bláha L (2011) Effects of microcystin and complex cyanobacterial samples on the growth and oxidative stress parameters in green alga Pseudokirchneriella subcapitata and comparison with the model oxidative stressorherbicide paraquat. Environ Toxicol 26:641-648

Bar-Yosef Y, Sukenik A, Hadas O, Viner-Mozzini Y, Kaplan A (2010) Enslavement in the water body by toxic Aphanizomenon ovalisporum, inducing alkaline phosphatase in phytoplanktons. Curr Biol 20:1557-1561

Bernard C, Harvey M, Briand JF, Biré R, Krys S, Fontaine JJ (2003) Toxicological comparison of diverse Cylindrospermopsis raciborskii strain: evidence of liver damage caused by a French C. raciborskii strain. Environ Toxicol 18:176-186

Bittencourt-Oliveira MC (2003) Detection of potential microcystinproducing cyanobacteria in Brazilian reservoirs with a $m c y \mathrm{~B}$ molecular marker. Harmful Algae 2:51-60

Bittencourt-Oliveira MC, Oliveira MC, Pinto E (2011) Diversity of microcystin-producing genotypes in Brazilian strains of Microcystis (Cyanobacteria). Braz J Biol 71:209-216

Bittencourt-Oliveira MC, Chia AM, Oliveira HSB, Cordeiro-Araújo MK, Molica RJR, Dias CTS (2015) Allelopathic interactions between 
microcystin-producing and non-microcystin-producing cyanobacteria and green microalgae: implications for microcystins production. J Appl Phycol 27:275-284

Bouvy M, Molica R, de Oliveira S, Marinho M, Beker B (1999) Dynamics of a toxic cyanobacterial bloom (Cylindrospermopsis raciborskii) in a shallow reservoir in the semi-arid region of northeast Brazil. Aquat Microb Ecol 20:285-297

Bouvy M, Ba N, Ka S, Sane S, Pagano M, Arfí R (2006) Phytoplankton community structure and species assemblage succession in a shallow tropical lake (Lake Guiers, Senegal). Aquat Microb Ecol 45: 147-161

Campos A, Araújo P, Pinheiro C, Azevedo J, Osório H, Vasconcelos V (2013) Effect on growth, antioxidant enzyme activity and levels of extracellular proteins in the green alga Chlorella vulgaris exposed to crude cyanobacterial extracts and pure microcystin and cylindrospermopsin. Ecotoxicol Environ Saf 94:45-53

Carneiro RL, Pacheco ABF, Azevedo SMFO (2013) Growth and saxitoxin production by Cylindrospermopsis raciborskii (Cyanobacteria) correlate with water hardness. Mar Drugs 11: 2949-2963

Chia AM, Abolude DS, Ladan Z, Akanbi O, Kalaboms A (2009a) The presence of microcystins in aquatic ecosystems in Northern Nigeria: Zaria as a case study. Res J Environ Toxicol 3:170-178

Chia AM, Oniye SJ, Ladan Z, Lado Z, Pila EA, Inekwe VU, Mmerole JU (2009b) A survey for the presence of microcystins in aquaculture ponds in Zaria, Northern-Nigeria: possible public health implication. Afr J Biotechnol 8:6282-6289

Chia AM, Adelanwa MA, Ladan Z, Iortsuun DN, Adanyi SE, Stephen BJ (2012) Interactions of Ipomoea aquatica and Utricularia reflexa with phytoplankton densities in a small water body in northern Nigeria. Oceanol Hydrobiol Stud 41:39-47

Cordeiro-Araújo MK, Bittencourt-Oliveira MC (2013) Active release of microcystins controlled by an endogenous rhythm in the cyanobacterium Microcystis aeruginosa. Phycol Res 61:1-6

Costa SM, Ferrão-Filho AS, Azevedo SMFO (2013) Effects of saxitoxinand non-saxitoxin-producing strains of the cyanobacterium Cylindrospermopsis raciborskii on the fitness of temperate and tropical cladocerans. Harmful Algae 28:55-63

Deblois CP, Juneau P (2010) Relationship between photosynthetic processes and microcystin in Microcystis aeruginosa grown under different photon irradiances. Harmful Algae 9:18-24

Downing TG, Meyer C, Gehringer MM, Van de Venter M (2005) Microcystin content of Microcystis aeruginosa is modulated by nitrogen uptake rate relative to specific growth rate or carbon fixation rate. Environ Toxicol 20:257-262

Dunker S, Jakob T, Wilhelm C (2013) Contrasting effects of the cyanobacterium Microcystis aeruginosa on the growth and physiology of two green algae, Oocystis marsonii and Scenedesmus obliquus, revealed by flow cytometry. Freshw Biol 58:1573-1587

Figueredo CC, Giani A, Bird DF (2007) Does allelopathy contribute to Cylindrospermopsis raciborskii (Cyanobacteria) bloom occurrence and geographic expansion? J Phycol 43:256-265

Fistarol GO, Legrand C, Selander E, Hummert C, Stolte W, Granéli E (2004) Allelopathy in Alexandrium spp.: effect on a natural plankton community and on algal monocultures. Aquat Microb Ecol 35:45-56

Gan N, Xiao Y, Zhu L, Wu Z, Liu J, Hu C, Song L (2012) The role of microcystins in maintaining colonies of bloom-forming Microcystis spp. Environ Microbiol 14:730-742

Guillard RRL (1973) Division rates. In: Stein J (ed) Handbook of phycological methods: culture methods and growth measurements. Cambridge University Press, Cambridge, pp 289-311

Hattenrath-Lehmann TK, Gobler CJ (2011) Allelopathic inhibition of competing phytoplankton by North American strains of the toxic dinoflagellate, Alexandrium fundyense: evidence from field experiments, laboratory experiments, and bloom events. Harmful Algae 11:106-116

Hoff-Risseti C, Dörr FA, Schaker PDC, Pinto E, Werner VR, Fiore MF (2013) Cylindrospermopsin and saxitoxin synthetase genes in Cylindrospermopsis raciborskii strains from Brazilian freshwater. Plos One 8(8):e74238

Kaplan A, Harel M, Kaplan-Levy RN, Hadas O, Sukenik A, Dittmann E (2012) The languages spoken in the water body (or the biological role of cyanobacterial toxins). Front Microbiol 3:138

Kling HJ (2009) Cylindrospermopsis raciborskii (Nostocales, Cyanobacteria): a brief historic overview and recent discovery in the Assiniboine River (Canada). Fottea 9:45-47

Kokociński M, Stefaniak K, Mankiewicz-Boczek J, Izydorczyk K, Soininen J (2010) The ecology of the invasive Cylindrospermopsis raciborskii (Nostocales, Cyanophyta) in two hypereutrophic lakes dominated by Planktothrix agardhiii (Oscillatoriales, Cyanophyta). Eur J Phycol 45:365-374

Lagos N, Onodera H, Zagatto PA, Andrinolo D, Azevedo SMFO, Oshima Y (1999) The first evidence of paralytic shellfish toxins in the freshwater cyanobacterium Cylindrospermopsis raciborskii, isolated from Brazil. Toxicon 37:1359-1373

Landsberg J (2002) The effects of harmful algal blooms on aquatic organisms. Rev Fish Sci 10:113-390

Leão PN, Vasconcelos MTSD, Vasconcelos VM (2009) Allelopathic activity of cyanobacteria on green algae at low densities. Eur J Phycol 44:347-355

Lund JWG, Kipling C, Le Cren ED (1958) The inverted microscope method of estimating algal numbers and the statistical basis of estimations by counting. Hydrobiologia 11:143-170

Melegari SP, Perreault F, Moukha S, Popovic R, Creppy EE, Matias WG (2012) Induction to oxidative stress by saxitoxin investigated through lipid peroxidation in Neuro 2A cells and Chlamydomonas reinhardtii alga. Chemosphere 89:38-43

Mello MME, Soares MCS, Roland F, Lürling M (2012) Growth inhibition and colony formation in the cyanobacterium Microcystis aeruginosa induced by the cyanobacterium Cylindrospermopsis raciborskii. J Plankton Res 34:987-994

Molica R, Onodera H, García C, Rivas M, Andrinolo D, Nascimento S, Meguro H, Oshima Y, Azevedo S, Lagos N (2002) Toxins in the freshwater cyanobacterium Cylindrospermopsis raciborskii (Cyanophyceae) isolated from Tabocas reservoir in Caruaru, Brazil, including demonstration of a new saxitoxin analogue. Phycologia 41:606-611

Moustaka-Gouni M, Vardaka E, Tryfon E (2007) Phytoplankton species succession in a shallow Mediterranean lake (L. Kastoria, Greece): steady-state dominance of Limnothrix redekei, Microcystis aeruginosa and Cylindrospermopsis raciborskii. Hydrobiologia 575:129-140

Neilan BA, Pearson LA, Muenchhoff J, Moffitt MC, Dittmann E (2013) Environmental conditions that influence toxin biosynthesis in cyanobacteria. Environ Microbiol 15:1239-1253

Orr PT, Jones GJ (1998) Relationship between microcystin production and cell division rates in nitrogen-limited Microcystis aeruginosa cultures. Limnol Oceanogr 43:1604-1614

Oshima Y (1995) Postcolumn derivatization liquid-chromatographic method for paralytic shellfish toxins. J AOAC Int 78:528-532

Perreault F, Matias MS, Melegari SP, Pinto CRSC, Creppy EK, Popovic R, Matias WG (2011) Investigation of animal and algal bioassays for reliable saxitoxin ecotoxicity and cytotoxicity risk evaluation. Ecotoxicol Environ Saf 74:1021-1026

Pineda-Mendoza RM, Zúñiga G, Martínez-Jerónimo F (2014) Infochemicals released by Daphnia magna fed on Microcystis aeruginosa affect $m c y A$ gene expression. Toxicon 80:78-86

Poniedzialek B, Rzymski P, Kokocinski M, Karczewski J. (2015). Toxic potencies of metabolite (s) of non-cylindrospermopsin producing 
Cylindrospermopsis raciborskii isolated from temperate zone in human white cells. Chemosphere 120:608-614

Rzymski P, Poniedzialek B (2014) In search of environmental role of cylindrospermopsin: a review on global distribution and ecology of its producers. Water Res 66:320-337

Rzymski P, Poniedzialek B, Kokociński M, Jurczak T, Lipski D, Wiktorowicz K (2014) Interspecific allelopathy in cyanobacteria: cylindrospermopsin and Cylindrospermopsis raciborskii effect on the growth and metabolism of Microcystis aeruginosa. Harmful Algae 35:1-8

Schatz D, Keren Y, Vardi A, Sukenik A, Carmeli S, Borner T, Dittmann E, Kaplan A (2007) Towards clarification of the biological role of microcystins, a family of cyanobacterial toxins. Environ Microbiol 9:965-970

Suikkanen S, Fistarol GO, Graneli E (2004) Allelopathic effects of the Baltic cyanobacteria Nodularia spumigena, Aphanizomenon flosaquae and Anabaena lemmermannii on algal monocultures. J Exp Mar Biol Ecol 308:85-101

Sukenik A, Hadas O, Kaplan A, Quesada A (2012) Invasion of Nostocales (cyanobacteria) to subtropical and temperate freshwater lakes - physiological, regional, and global driving forces. Front Microbiol 3:86

Taylor AR (2009) A fast $\mathrm{Na}^{+} / \mathrm{Ca}^{2+}$-based action potential in a marine diatom. PLoS One 4(3):e4966

Tillmann U, John U (2002) Toxic effects of Alexandrium spp. on heterotrophic dinoflagellates: an allelochemical defence mechanism independent of PSP-toxin content. Mar Ecol Prog Ser 230:47-58
Tillmann U, Tilman A, John U, Cembella A (2008) Allelochemical interactions and short-term effects of the dinoflagellate Alexandrium on selected photoautotrophic and heterotrophic protists. Harmful Algae 7:52-64

Van Gremberghe I, Vanormelingen P, van der Gucht K, Mancheva A, D'Hont S, de Meester L, Vyverman W (2009) Influence of Daphnia infochemicals on functional traits of Microcystis strains (cyanobacteria). Hydrobiologia 635:147-155

Velzeboer RMA, Baker PD, Rositano J, Heresztyn T, Codd GA, Raggett SL (2000) Geographical patterns of occurrence and composition of saxitoxins in the cyanobacterial genus Anabaena (Nostocales, Cyanophyta) in Australia. Phycologia 39:395-407

Wheeler GL, Brownlee C (2008) $\mathrm{Ca}^{2+}$ signalling in plants and green algae - changing channels. Trends Plant Sci 13:506-514

Wiegand C, Pflugmacher S (2005) Ecotoxicological effects of selected cyanobacterial secondary metabolites: a short review. Toxicol Appl Pharmacol 204:201-218

Wilken S, Wiezer S, Huisman J, van Donk E (2010) Microcystins do not provide anti-herbivore defence against mixotrophic flagellates. Aquat Microb Ecol 59:207-216

Zalocar de Domitrovic Y, Poi de Neiff ASG, Casco SL (2007) Abundance and diversity of phytoplankton in the Paraná River (Argentina) $220 \mathrm{~km}$ downstream the Yacyretá reservoir. Braz J Biol 67:53-63

Zhang P, Zhai C, Wang X, Liu C, Jiang J, Xue Y (2013) Growth competition between Microcystis aeruginosa and Quadrigula chodatii under controlled conditions. J Appl Phycol 25:555-565 